\title{
A Systematical Method to Evaluate Omnipork's Market Competitiveness Ability
}

\author{
Suye Zhang ${ }^{1, *, \dagger}$, Junchao $\mathrm{Xia}^{2, \dagger}$, Ming Yang ${ }^{3, \dagger}$, Xiaoxiao $\mathrm{Shi}^{4, \dagger}$, and Kejie Zhu ${ }^{5, \dagger}$ \\ ${ }^{I}$ The College of Arts and Sciences, Syracuse University, United States \\ ${ }^{2}$ Chongqing BI Academy, China \\ ${ }^{3}$ Sewickley Academy, United States \\ ${ }^{4}$ Shanghai World Foreign Language Academy, China \\ ${ }^{5}$ Salesian College Preparatory, United States \\ * Corresponding author: e-mail: szhan154@syr.edu \\ these authors contributed equally.
}

\begin{abstract}
Traditional livestock farming generates a huge amount of greenhouse gas that will harm our environment. With the improvement of the technology, plant-based meat has become a reality. Plant-based meat is considered a perfect substitute for traditional meat since it will not generate greenhouse gas during production. However, the existing literature rarely studies the benefit of plant-based meat, and only a few articles are evaluating the plant-based meat companies. A plant-based pork company from Hong Kong will be introduced and evaluate if it is worth investing. Methods are used to analyze the company, including market analysis, target customer analysis, company competitiveness analysis, and company financial status analysis. The result indicates the company is competitive in the industry, and we are optimistic about its future development. This paper aims to provide a creditable analysis for the public investors who are interested in investing plant-based companies.
\end{abstract}

Keywords: pork company; company competitiveness analysis; financial status analysis.

\section{INTRODUCTION}

For many years, people have the preconception that food satisfies nothing more than our fundamental need of subsistence. However, with the improvement in life quality, people started to focus on what else can food provide, and many have higher expectation on their diet. For most occasions, people want to be healthy and fit. Therefore, they always have to hesitate between meat, which they prefer for its taste and nutrition, and vegetable, which is considered as the healthier diet. It seems to be impossible to solve the dilemma especially in the modern society where foods are provided in more ways than ever before. However, since 2014, a company has been concerning about the trend of more serious "omnivore's dilemma", which is known as the ultimate question of mankind. It is the Omnipork, a firm produces artificial pork made of beans and other vegetables, which perfectly combine the taste of meat with the nutrition of vegetable. It aims at the wide Asian market which has rarely been put into consideration by other artificial meat producers and embraces the great potential of billions of pork consumers.

The analysis of this company provides an opportunity to explore how a start-up company can gain its financial support from various sources through its financing strategies. As a result, we have done research on the company's partner relationship, management team, product feature, market size, customers and financial forecast.

We review some of the articles to present the business models. SWOT analysis is a commonly used framework in the business field, and the growing use of virtual reality technology in the field of rehabilitation and treatment is analyzed here [1-3]. SWOT analysis can also be used to conclude that healthcare organizations are mainly professional network organizations, rather than bureaucratic systems [5-7]. Also, SWOT method can help firms to decide how to improve their competition ability [8]. Leigh [9] used SWOT analysis to conclude that the most powerful primary health care personnel in Pakistan, namely female health workers, should be used 
effectively and efficiently, and more political commitments need to be made at the highest level. Helms and Nixon [10] used SWOT method find ways to develop marine recreational sports. The results of the study are as follows. First of all, the expansion of base strength in South Korea is the concern of the government and local governments, and the use of existing facilities and various plans has expanded the local activities of marine leisure sports.

This article will evaluate a plant-based pork company in Hong Kong and determine if it is worth investing. The methods we employ to analyze the company includes market analysis, target customer analysis, SWOT analysis, and company financial status analysis. The first method we used to evaluate the company is market analysis, which includes the current market size and the market growth rate per year. We think that the plant-based pork market is full of potential and is worth to invest. It is a brand-new market with huge potential demands, and there are not many competitors in the industry. The second method we use to evaluate the company is target customer analysis. Targeting important customers will help the company sell more products at a relatively lower cost. Asian people, vegetarians, and obese people are three groups of people we are targeting. These groups of people are more likely to buy a company's product due to various reasons. We then use SWOT analysis to analyze the company's competitiveness. An analysis company's major competitors' strengths, weaknesses, threats, and opportunities during this section can be seen. SWOT analysis will provide investors a clear understanding of the company's competitiveness. The company's financial status analysis will be our last tool to evaluate OMN!Pork. We will determine the company's financial status from four aspects: revenue, capital structure, asset, and liability. The company is financially healthy and worth investing based on important financial indicators such as debt and liability ratio. The analysis of the company will provide a better understanding of the value of the company and help investors to evaluate the company.

In this article, we will first introduce the basic information about the company. We will present the company's background, partnership, and products in section 2 . We will then analyze the global meat market, target customer, and company's competitiveness. We will provide sales strategies for the company based on previous analysis in section 3. This article will then evaluate Omn!Pork from the company's financial status in section 4. Last but not the least, section 5 will be a conclusion of the whole paper.

\section{FIGURES AND TABLES}

In this part, we introduced the related information for Omn!Pork. And ever since 2014, a company has been concerning about the trend of a more serious "omnivore's dilemma", which is known as the ultimate question of mankind. It is the Omn!Pork, a firm that produces artificial pork made of beans and other vegetables. The analysis of this company provides an opportunity to explore how a start-up company can gain financial support from various sources through its financing strategies. As a result, we have done research on the company's partner relationship, management team, product feature, market size, customers, and financial forecast.

\subsection{Company's Partnership}

Omn!Pork has a well-developed partnership network. Partners of the company included multinational corporations, restaurants, and online stores. Omn!Pork has cooperation with Swire Group and they will provide products for one of the largest airline companies in the world: Cathay Pacific. Cathay Pacific will the first airline company in the world to introduce plant-based meat into their airplane meal. People can now enjoy plant-based pork even they are over thousand feet above the ground. The company also made a deal with 7-11 and now their product will be available to purchase in over 700 7-11 stores across Hong Kong. Omn!Pork pay close attention to cooperation with local restaurants. They already team up with many local restaurants and hotels across Asia. Their partner included Royal Plaza Hotel in Hong Kong, Eight Treasures in Singapore, and Seven Salad in Macao. Last but not least, Omn!Pork already set up an online website on Tianmao, it is the first step of the company's attempt to open the China Market.

\subsection{Plant-Based Pork Advantages Compare with Pork}

The product of the company is plant-based pork that has advantages compared with traditional pork. First of all, their product is healthier than traditional pork. There are less fat and calorie with more useful trace elements for people's bodies. Also, their product is produced in the factory that can maintain a stable supply for production. One significant drawback of traditional livestock farming is the livestock may get infectious diseases on the farm. Their product is made with vegetables, which is environmentally friendly and it will prevent the spread of infectious diseases.

\section{MARKET ANALYSIS}

\subsection{Meat Market Analysis}

The plant-based meat market is now valued at around 12 billion dollars. Market analysis agencies expect the industry market growth around 7 to 10 times in 10 years. UBS believes that the size of the global plant protein market will rise to $\$ 85$ billion dollars in 2030 and 
Barclays Bank believes that the market size of artificial meat is expected to reach $\$ 140$ billion dollars in 10 years.

We can see from the graph that the Asia market only accounts for a small part of the global market right now. We think the major reason for this phenomenon is plantbased meat companies have not focused on exploring the Asian market yet and it is a good signal for our company's future development. Because there are no competitors in the market right now just like Beyond Meat first enter the industry 10 years ago. Asia accounted for 60 percent of the world's pork consumption in 2017. And China is the world's largest consumer of pork, accounting for 47 percent of the world's total consumption. If we look at the global pork consumption chart on the right. We would actually find out China consumes much more pork compared with the rest of the world. The potential market for our company is huge. A recent survey shows that $74 \%$ of Chinese consumers are willing to try plant-based meat. With the enhancement of consumer health, environmental protection awareness, and the improvement of biotechnology, people are more likely to accept plant-based meat.

Plant-based meat will enter a period of rapid development globally. The demand for plant-based meat is set to increase to a valued $200 \%$ over the next five years in major Asian markets, according to a new research report. The research also predicts the market size for plant-based meat across the entire Asian region will continue to grow.

\subsection{Target Consumers Analysis}

The first group of people that we are targeting is Asian people. Unlike Europe and America, Vegetarianism has always existed in Asia, and people eating a meatless diet can be dated back thousands of years ago. Vegan dishes first appears in the Tang Dynastic and become popular in the Song Dynasty. Religion is another important reason for us to decided target Asian people to be our potential customers. Some branch of Buddhist believer used to be vegetarian as a way of self-cultivation and plant-based meat could be an alternative choice for them.

The second group of people we are targeting is vegetarian, they consume the only vegetables in their diet. And our product is a perfect fit with their requirement.

Lastly, the producst have less fat and calorie compare to traditional pork. Our product is design for people who can't give up meat but want to lose weight?

\subsection{Competitiveness Analysis}

Our company Omni Pork focuses on artificial meat. Because we want to be the benchmark in the artificial pork industry, we choose our biggest competitors as Beyond Meat and Impossible Food.

This part will use SWOT analysis to determine how much menace will bring to us from such companies and how far we should cover to catch up with such companies.

\section{Beyond Meat}

\section{(1) Strength}

Beyond Meat is considered one of the earliest artificial meat companies in the world. They entered this market in 2009, which helped them occupy a large market share because there were no competitors when they first entered. Its competitors, like impossible food, entered this market in 2011. Therefore, they received much funding from investors such as Bill Gates, Evan Williams) co-founder of Twitter (, and Tyson food (the biggest meat producer in the U.S.), which made the value of the company become 11.7billion dollars. The funding they received will help them develop their technology to make their product taste more authentic to make their occupation in the market stable.

Beyond Meat is the first company that made its IPO with a year net revenue of over a hundred million dollars setting up a great retail network across the nation. Their capital will allow their company to put more funding on technology development, research team recruiting, and buying high-tech equipment. Thus, the company will develop many leading technologies, and the money will keep the company in a leading position in the industry.

Beyond Meat has developed great relationships with major quick-serve restaurant companies. Cooperating with big restaurants and quick-serve companies would be a great way to sell their product. Beyond Meat announces they make three years deal with McDonald's; they will provide artificial meat patty for one of their products. Also, Taco Bell's Beyond Meat partnership is official; this new partnership adds to Beyond Meat's growing list of fast-food clients.

\section{(2) Weakness}

Consumers will be concerned about the multiple ingredients in such artificial Meat. Unfortunately, Beyond Meat uses coconut oil, which is a saturated fat associated with cardiovascular disease.

The categories of products beyond Meat are insufficient. Products do include some human meat needs, but Beyond Meat develops only a few varieties of products, which can hardly satisfy customers' needs to a larger extent. For example, the company has not rolled out substitutes for lamps or seafood yet.

\section{(3) Opportunity}

With obesity and other health issues attracting more attention than any other issues, people switch to healthier 
diets, showing more organic and plant-based foods. Beyond Meat is the provider of such a diet.

Countries like China and Vietnam officially banned trading or eating wild since the COVID-19 pandemic. Fear of diseases from animals, more and more people are considering vegan diets. Beyond Meat can catch the trends and try to make more authentic meat products.

a $600 \%$ increase in the population of vegans in the United States over the last three years. According to the Good Food Institution, nearly $33.3 \%$ of Americans consider themselves flexitarians, who are craving more plant-based meals, and the number of this population is still climbing

The meat-free products save animals and significantly reduce Greenhouse Gas Emissions (GHGE) and the use of natural resources. According to an analysis published by the University of Michigan, a Beyond Burger uses $99 \%$ less water, 93\% less land, 90\% less GHGE, and $46 \%$ less energy than a $1 / 4 \mathrm{lb}$ U.S. beef burger.

\section{(4) Threat}

Nowadays concept the company's sales are growing slowly due to the pandemic in the United States. Because some cities in the United States have been suffered lockdown, some consumers cannot go to supermarkets. The sales of such products in the supermarket suffer. Also, Supermarket sales still make up the bulk of its turnover.

Difficulty in opening new markets. Stereotypes like "only meat makes people stronger" are still popular in some areas, especially China. This stereotype will make people still prefer to eat some real meat instead of artificial ones. It's hard for beyond Meat to open a new market in such an area.

Increase in competitors. Nowadays, more and more meat producers try to make their artificial Meat. Therefore, food tech companies like Impossible Foods and even traditional food brands like Tyson Foods are developing vegan offerings. Such actions from those companies will gradually occupy the market share of artificial Meat.[5]

Impossible Food

(1) Strength

The founder of impossible food is a Stanford professor who focuses on biochemistry. Great academic background and networking from the founder will help the company build a skillful team for product research and development.

Impossible food also has technical advances in meat quality. A research team in impossible food found one useful heme from soybean to enhance Meat's nutrition and taste. Artificial Meat from impossible food looks more like real beef compared to other competitors.

Impossible food earns investor favor across the globe and received over 1.3 billion dollars of investment. There is a ton of money, and Impossible food can use it to take up a big market share. Their CEO reported that they would use this money to focus on new products such as sausage and pork and to develop their retail network across the globe. (Series-E earn 300 million and SeriesF earn over 500 million)

\section{(2) Weakness}

First, the company uses some additives like heme in their product. Although government allows this, some people feel that the additive will damage the health. For example, making such artificial Meat in the Impossible Food required some Binders, methylcellulose, and food starch to combine such Meat. However, some consumers still believe such ingredients are harmful to human health, even if the United States government allows using such chemical.

The Meat is expensive. Even though the company decreases the price, their price is higher than the normal Meat, about triples the ground beef price. In the United States, consumers pay from $\$ 3$ to $8 \$$ dollars to purchase ground beef; even in New York, one pound of Meat costs consumers 8 . However, for Impossible Food, less than one pound of Meat, about 12 ounces, costs $9 \$$.

\section{(3) Opportunity}

Because of investments the Impossible received, this company can have a huge potential in $R \& D$ development. In the early stage, the research department found a useful heme from soybeans. Therefore, this department can use the funding to find some helpful chemicals in the vegetation.

Although the COVID-19 kills many animals and euthanizes millions of animals, this does not significantly impact their supply chain because their supply chain does not include animals, including plants and vegetations. Therefore, their food chain is meaningfully more robust than the meat industry.

\section{(4) Thread}

Their production lines have not been able to keep up with the growing demand for plant protein, with their competitor develop a capable production line. Their products are much more expensive than other artificial Meat because of such a low productivity production line. However, their competitor, like Beyond Meat, has a stronger production line than its.

The production and development of Lab-grown Meat are highly relying on the development of technology. However, under the impact of COVID-19, R\&D developed slower because some cities shot-downed. 
They do not have enough security to make sure a safe atmosphere.

\subsection{Strategies Suggestion}

Based on the above analysis, we obtain the following strategies.

Our first sales strategy is to improve meat texture and make it taste like real meat. It will be easier for consumers to accept our product if our product's texture has little or no different compare with traditional meat.

Our second strategy is to lower the cost of our production, so we can make our product become more affordable for the public. The price of real meat is around $25 \mathrm{RMB}$ for $500 \mathrm{~g}$, the price of our products is much higher right now. It is going to cost us 58RMB for $500 \mathrm{~g}$ of plant-based pork. The huge price gap between real pork and plant-based pork will become a drawback when our company trying to sell our product to the public. The cost of product development makes artificial meat become very expensive. Since the raw material is very cheap, our products will have a lot of room for the price reduction. The industry is expecting the price of plantbased meat will be the same as traditional meat in 2024 . To open up the market and attract consumers, setting a lower price will help win consumer recognition and eventually increase the company's sales.

We are also going to develop a serious of product to our customer. Diversified product categories will help us

to explore a bigger group of customers, and thus increase the company's sales.

Last but not least, we will adjust the composition of products to meet the needs of consumers. Consumers are more willing to buy products that fit their needs or habit. It is very useful epically in the food industry, a quickserve restaurant such as KFC, McDonald's, and Pizza hut even develop a completely different menu to target a different group of people in a different region.

\section{FINANCIAL STATEMENT ANALYSIS}

We are going to use our biggest competitor, Beyond Meat, as a reference during analysis. Beyond Meat's data from 2018 to 2020 are come from their annual financial report, and we will use the trend to forecast the company's future development. The trend is defined as

$$
\text { Trend }=\frac{\text { (Present Year }- \text { Based Year) }}{\text { Based Year }}
$$

Omn!Pork is a privately own company that did not release any financial information online. We think Omn! Pork is in a position that very similar to Beyond Meat in 2018 right now. Both companies are occupying part of the market share and seeking capital for development. We will employ Beyond Meat's data in the 2018 financial report to analyze Omn! Pork financial status. We will also employ trends from Beyond Meat with adjustments since Omn! Pork is based in Asia, and Beyond Meat is based in the U.S.

\subsection{Company Revenue Analysis}

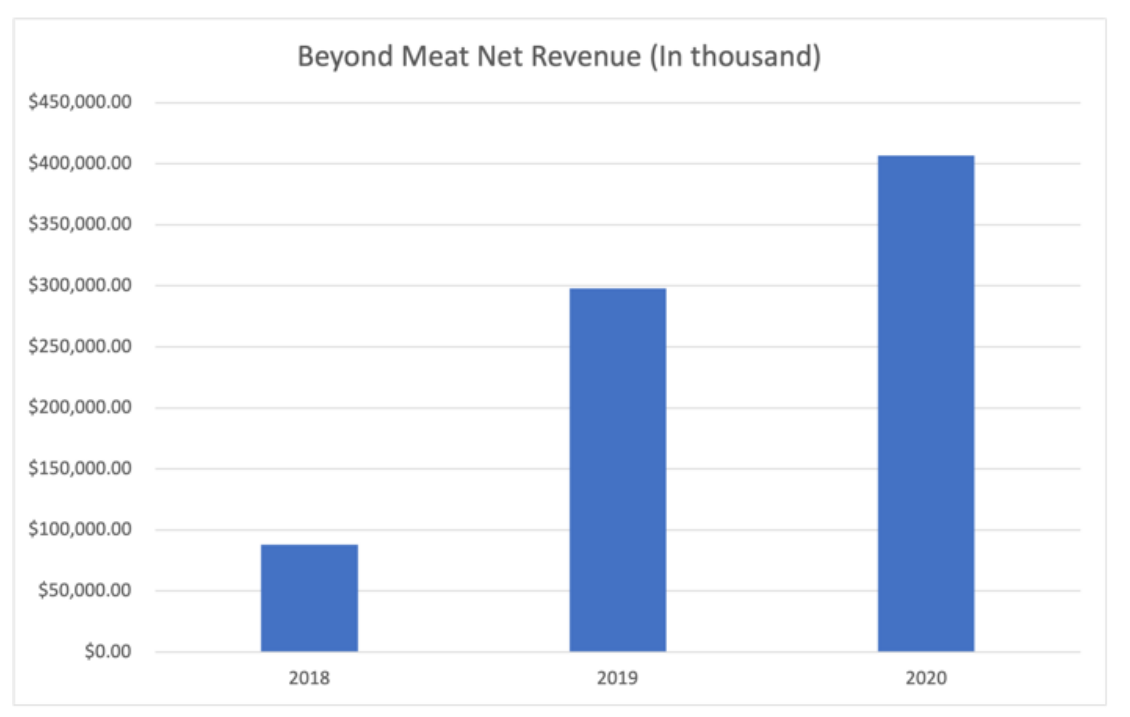

Fig. 1. Beyond Meat Net Revenue from 2018 to 2020 (In thousands)

According to Beyond Meat's annual financial report, company net revenues in 2020 reached 406.8 million dollars. The company's net revenue experienced a $239 \%$ increase compared to 2018. The pandemic deeply impacted the company and they end up with net revenue of \$406 million, a 36\% growth compared to last year. 


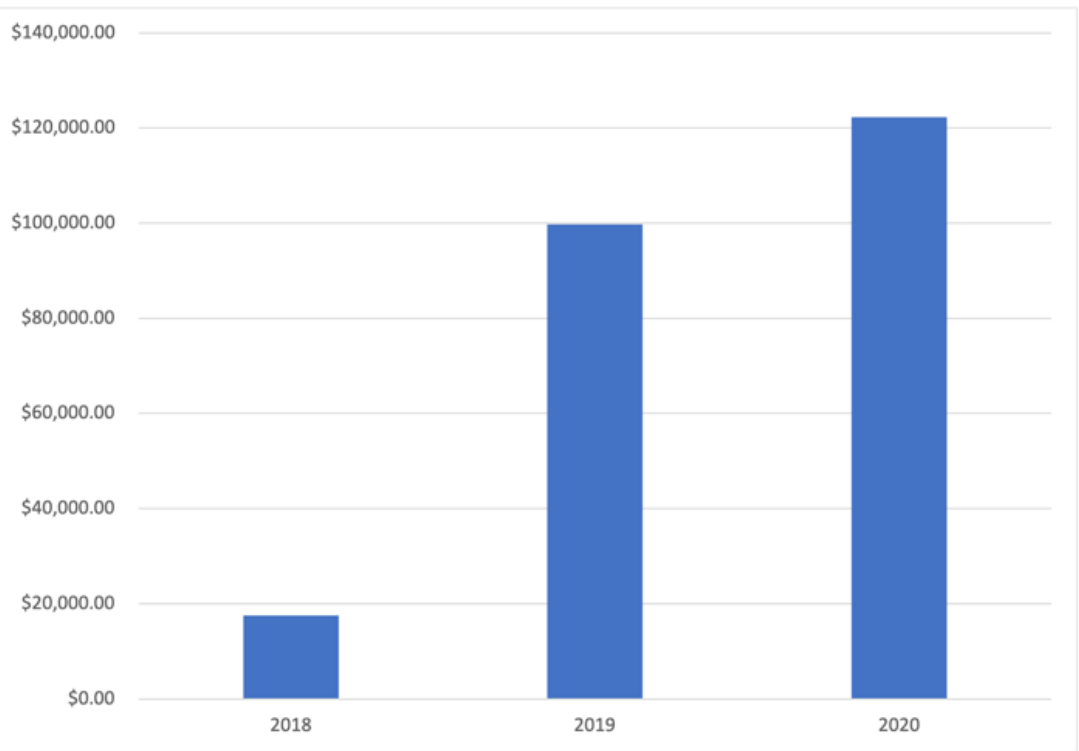

Fig. 2. Beyond Meat Gross Profit from 2018 to 2020 (In thousands)

The gross profit for Beyond Meat is shown in the figure above. Thanks to the rapid growth in net revenue, gross profit experience nearly $700 \%$ growth from 17.57 million in 2018 to 122 million dollars in 2020.

There is no doubt that 2019 is a wonderful year for Beyond Meat. Both total revenue and gross profit experience an astounding increase. Unfortunately, the company failed to keep this momentum in 2020. One of the major factors that affect the company's sales is the pandemic that results in city lockdown and closure of the factory. Beyond Meat report company fourth-quarter net revenues were $\$ 101.9$ million, only $3.5 \%$ growth compared to last year.
We assume Omn! Pork's net revenue for 2020 will be around 87 million dollars, and the company's net revenue growth rate will be around $80 \%$ in the next five years. We expect the net revenue will reach 512 million dollars in 2023. We assume the gross profit for Omn!Pork will be around $\$ 17$ million will an annual growth rate of $22 \%$. We expect the gross profit for the company will be around $\$ 150$ million in 2023. Unlike Beyond Meat experience slow sales growth, Omn! Pork's sales growth in 2020 has drastically increased. The founder of the company report company experience $500 \%$ to $600 \%$ in the first quarter of 2020 compared to the prior year.

\subsection{Capital Structure of Omn!Pork}

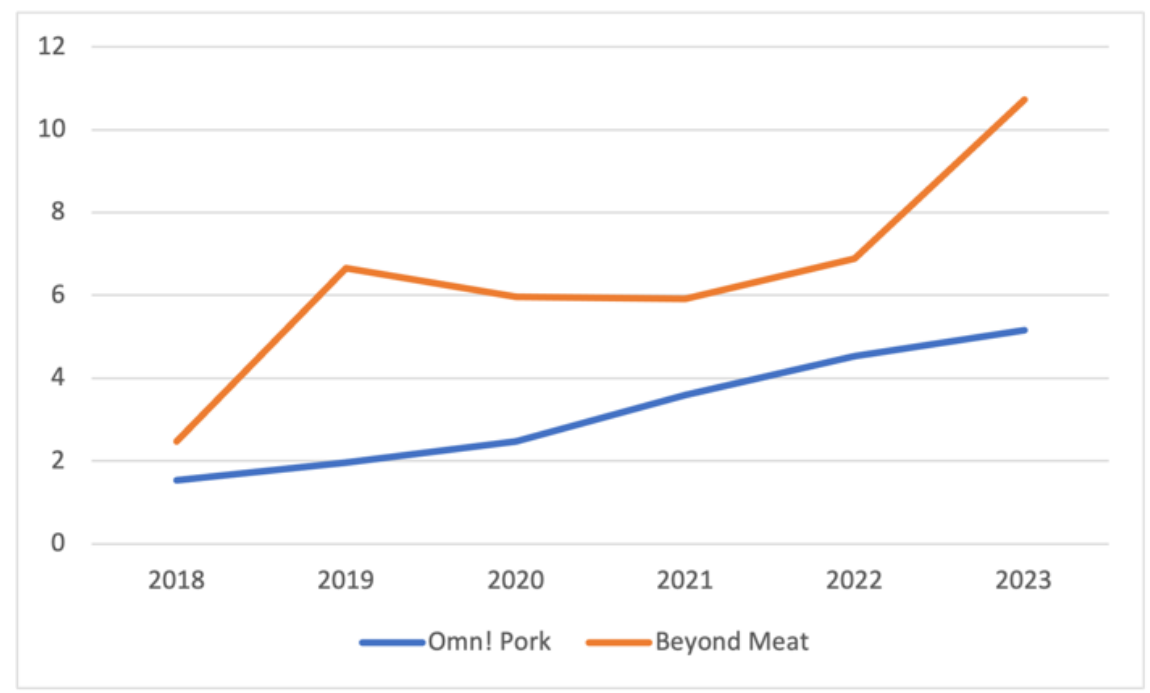

Fig. 3. Comparison of Current Ratio of OMN! Pork and Beyond Meat

The comparison of Beyond Meat and Omn! Pork is shown in figure 3 . One of the most important ratios investors pay attention to is the current ratio of the company. The formula defined as

$$
\text { Current Ratio }=\frac{\text { Current Asset }}{\text { Current Liability }}
$$

According to our assumption, Omn! Pork has a current ratio that above 1.5 , which means they have 
enough cash on their hand to pay back their debt. Investors are not likely to lose money by investing in the company.

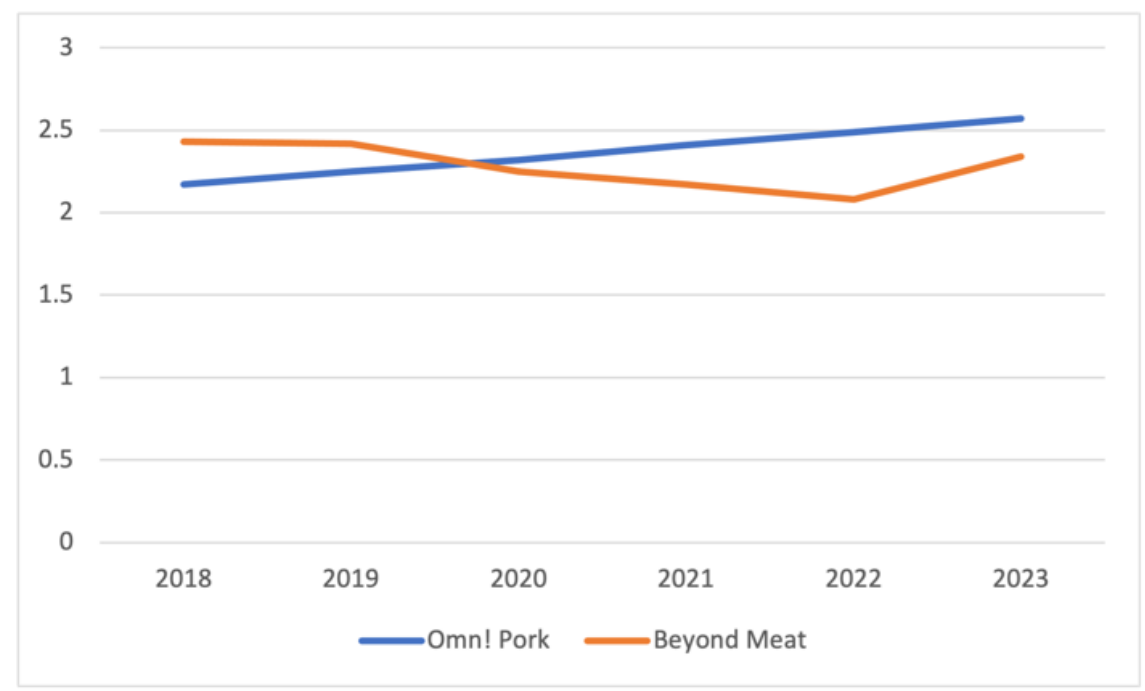

Fig. 4. Comparison of Inventory Turnover Ratio of Omn! Pork and Beyond Meat

The inventory turnover ratio of Beyond Meat and Omn!Pork is shown in figure 4. The company's inventory turnover is used to determine how long it takes for a company to turn inventory into products. The trend is defined as

Inventory Turnover Ratio $=\frac{\text { Cost of Goods Sold }}{\text { Average Inventory }}$
The inventory turnover ratio for both Omn! Pork and Beyond Meat is around 2.3. This indicates Omn!Pork is doing a great job on this aspect. It also suggests the company has a great management team to some degree because it shows they are doing a great job determining the product's price and how many materials should order at one time.

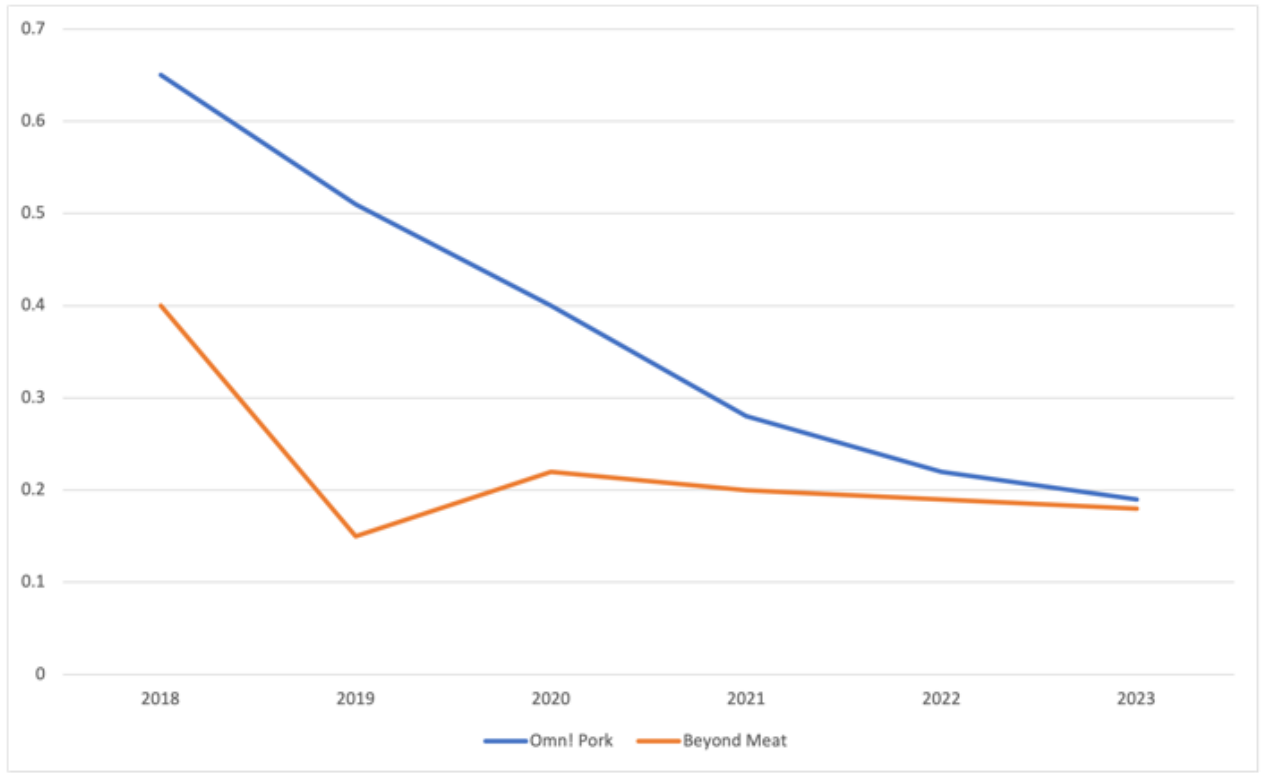

Fig. 5. Comparison of Debt and Asset Ratio of OMN! Pork and Beyond Meat

The debt and asset ratio from figure 5 show the comparison of debt and asset ratio of Omn!Pork and Beyond Meat. Omn!Pork's ratio is initially much higher than Beyond Meat. The graph becomes flattered as time goes by. The debt and asset ratio is a measure of a company's liability and assets. We can tell from the graph that Beyond Meat has a stable slope, indicating their relationship between liability and asset remains unchanged. While Omn!Pork can reduce the unit of liability for every asset unit, the ratio approach to the same level as Beyond Meat. 


\subsection{Asset and Liability}

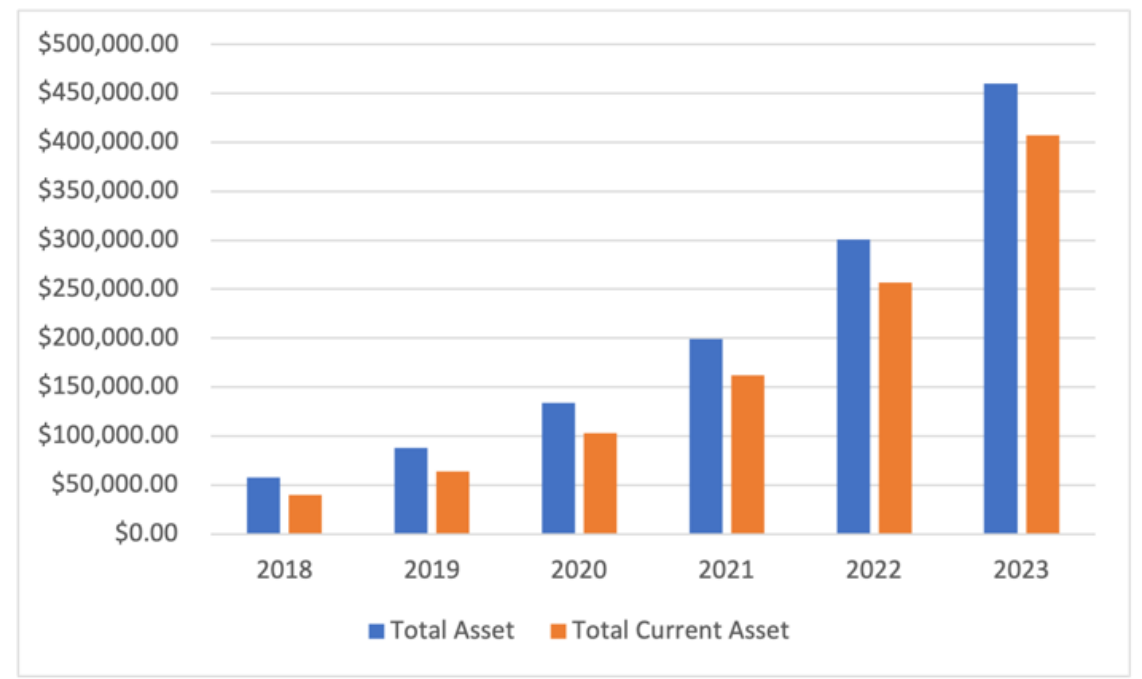

Fig. 6. Total Asset and Total Current Asset Forecast for Omn!Pork (In thousands)

The asset is one of the most important elements when investors evaluate a company's value. The prediction of total asset and total current asset for Omn!Pork is shown in Figure 6. It is the value of anything a company owns that can be converted into cash. The total asset for Omn!Pork is estimated at around $\$ 13.3$ million, and the total current asset for the company is around 10.2 million dollars.

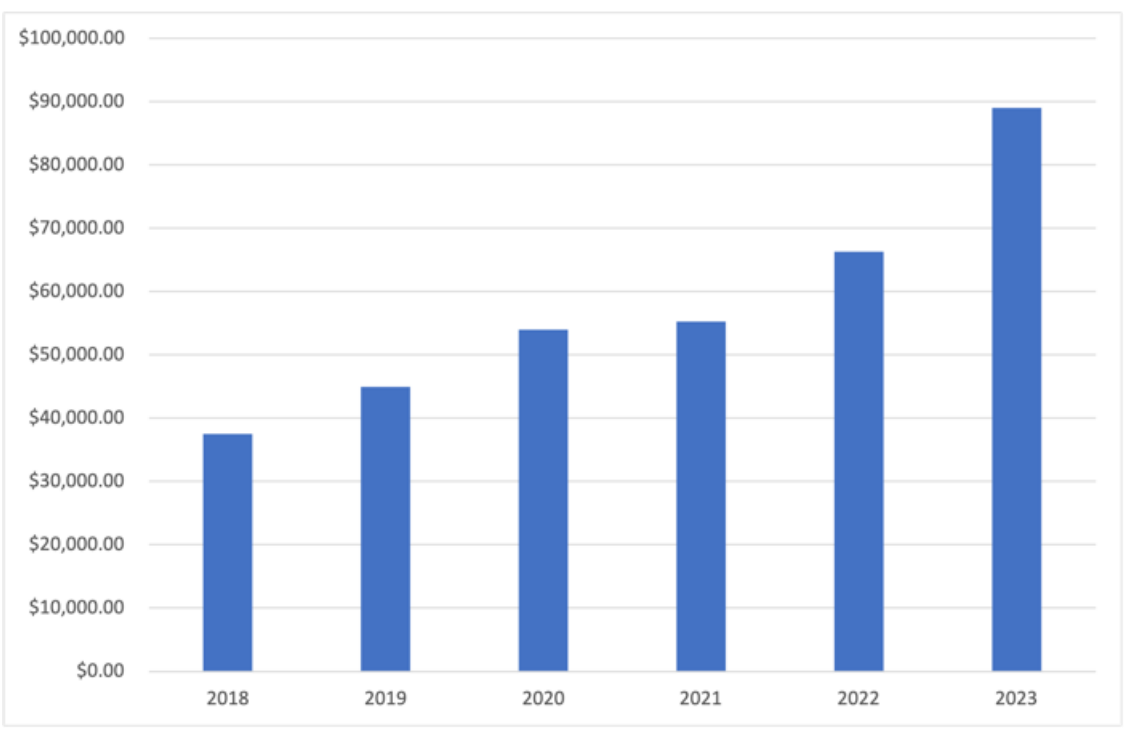

Fig. 7. Liability Forecast for Omn!Pork (In thousands)

Liability is another important element investors will focus on when they are evaluating a company. The total liability for Omn!Pork is shown in Figures 7, and we expect the liability for Omn! Pork will reach 89 million dollars at the end of 2023.

\section{CONCLUSION}

To recap, this research paper explores Omn!pork's company relationships, product features, market size, customers, and financial forecast. SWOT analysis is used to evaluate Omn!pork, which demonstrates the promising future of this company.
Then, we conduct the market analysis in this research. It is found that the artificial pork market in Asia is still full of potential. Most of the top ranked companies in the plant-based artificial meat industry are now focusing on the beef products. Omn!Pork is focusing on plant-based pork products, which will help the company gain an advantage in occupying a market share. Since vegetarianism has been existed in Asia for a long time, it will help companies develop new markets in Asian regions. Customers are very likely to try plant-based products. According to the financial analysis, a series of insights are proposed. 
The company is doing great according to the assumption. They are financially healthy: their annual growth rate for the net revenue increases, they have enough cash to develop new markets and pay back their debt, and they have relatively fast inventory turnover. Through the assumption of the financial in our article, we can get the conclusion that the company is operating well financially from the perspective of their annual growth rate for net revenue, amount of cash to develop new markets and pay back their debt, and their inventory turnover.

Overall, there are two shortcomings in this paper. To begin with, due to the lack of financial information of Omnipork online, the analysis of financial situation of Omnipork may be slightly inaccurate. In addition, the global pandemic also interferes us from getting the exact evaluation of this company. Thus, we expect more detailed information to be released in the future in order to let us have a better understanding of this company.

\section{REFERENCES}

[1]. Hill, T., \& Westbrook, R. (1997). SWOT analysis: it's time for a product recall. Long range planning, 30(1), 46-52.

[2]. Jackson, S. E., Joshi, A., \& Erhardt, N. L. (2003). Recent research on team and organizational diversity: SWOT analysis and implications. Journal of management, 29(6), 801-830.

[3]. HELlER, Martin C.; KEOLEIAN, Gregory A. Beyond Meat's Beyond Burger Life Cycle Assessment: A detailed comparison between. 2018.

[4]. Suh, D. H., Kang, M. G., \& Lee, S. Y. (2017). A Seach for Methods of Development of Marine Leisure Sport through the SWOT Analysis. Journal of Digital Convergence, 15(1), 537-546.

[5]. CUI, R. H., WANG, Z. Y., \& YU, W. Q. (2007). SWOT-PEST Analysis of Sport Industry in China. Journal of Tianjin University of Sport, 3, 018.

[6]. Wazir, M. S., Shaikh, B. T., \& Ahmed, A. (2013). National program for family planning and primary health care Pakistan: a SWOT analysis. Reproductive health, 10(1), 1-7.

[7]. van Wijngaarden, J. D., Scholten, G. R., \& van Wijk, K. P. (2012). Strategic analysis for health care organizations: the suitability of the SWOTü $\square$ analysis. The International journal of health planning and management, 27(1), 34-49.

[8]. Rizzo, A. S., \& Kim, G. J. (2005). A SWOT analysis of the field of virtual reality rehabilitation and therapy. Presence: Teleoperators \& Virtual Environments, 14(2), 119-146.
[9]. Leigh, D. (2009). SWOT analysis. Handbook of Improving Performance in the Workplace: Volumes $1 \ddot{u} \square 3,115-140$.

[10].Helms, M. M., \& Nixon, J. (2010). Exploring SWOT analysis-where are we now? A review of academic research from the last decade. Journal of strategy and management. 